\title{
The South Atlantic in the Fine-Resolution Antarctic Model
}

\author{
D. P. Stevens ${ }^{1}$, S. R. Thompson ${ }^{2}$ \\ ${ }^{1}$ School of Mathematics, University of East Anglia, Norwich, NR4 7TJ, UK \\ 2 Institute of Oceanographic Sciences Deacon Laboratory, Godalming, Surrey, GU8 5UB, UK
}

Received: 16 July 1993/Revised: 16 March 1994/Accepted: 23 March 1994

\begin{abstract}
The geographical area covered by the FineResolution Antarctic Model (FRAM) includes that part of the South Atlantic south of $24^{\circ} \mathrm{S}$. A description of the dynamics and thermodynamics of this region of the model is presented. Both the mean and eddy fields in the model are in good agreement with reality, although the magnitude of the transients is somewhat reduced. The heat flux is northward and in broad agreement with many other estimates. Agulhas eddies are formed by the model and propagate westward into the Atlantic providing a mechanism for fluxing heat from the Indian Ocean. The confluence of the Brazil and Falkland currents produces a strong front and a large amount of mesoscale aetivity. In the less stratified regions to the south, topographic steering of the Antarctic circumpolar current is important.
\end{abstract}

\section{Introduction}

The South Atlantic Ocean exhibits a diversity of dynamical processes and as such is of great interest to oceanographers. A review of the large-scale circulation has recently been carried out by Peterson and Stramma (1991), therefore only a brief description of the main features will be given here. The region under consideration lies between the equator and the southern flank of the Antarctic Circumpolar Current (ACC). To the north, equatorial dynamics dominate. Further south, there is a wind-driven sub-tropical gyre and western boundary current (the Brazil Current). The ACC enters the South Atlantic through Drake Passage. A branch flows northward as a western boundary current (the Falkland or Malvinas Current) while the remainder flows eastward across the Atlantic. At approximately $38^{\circ} \mathrm{S}$, the Brazil and Falkland Currents meet and separate from the coast. Some of this water forms a recirculation cell while the remainder forms the South Atlantic Current which closes the southern end of the subtropical gyre. At high latitudes in the Weddell

Correspondence to: D. Stevens
Sea there is a cyclonic gyre and Antarctic bottom water is formed. Coastal upwelling occurs along the south-west African coast. Eddies from the Agulhas Current retroflection, one of the most eddy-active regions in the World Ocean (Shum et al., 1990), 'invade' the South Atlantic (Gordon and Haxby, 1990), transporting large amounts of heat.

The South Atlantic plays an important part in the Earth's climate system. It is unusual amongst the world's oceans in providing an equatorward heat transport. Estimates of the northward heat transport, summarised by Rintoul (1991), vary from 0.04 to $1.15 \mathrm{PW}\left(\mathrm{PW}=10^{15} \mathrm{~W}\right)$. This transport is due to the thermohaline circulation in which relatively warm surface and intermediate waters flow northward and cold deep waters flow southward. The North Atlantic conveyor belt (Broecker, 1991) passes southward through the South Atlantic, at a depth of about $2500 \mathrm{~m}$, as North Atlantic Deep Water (NADW). It is then swept eastward in the ACC, with water upwelling in both the Indian and Pacific Oceans, before returning to the North Atlantic. There has been some discussion as to whether the returning upper ocean water takes the cold water path through Drake Passage (Rintoul, 1991; Broecker, 1991) or the warm water path around South Africa (Gordon, 1986).

\section{The model}

The FRAM project was a community research programme set up to make a detailed study of the Southern Ocean. Central to this study was a primitive equation eddy-resolving ocean general circulation model (Cox, 1984). A more detailed description of the model and some initial results can be found in the article by the FRAM group (1991). In FRAM, the South Atlantic (as well as the other oceans) is terminated at $24^{\circ} \mathrm{S}$ by an open boundary condition (Stevens, 1991). The horizontal resolution of the model is approximately $27 \mathrm{~km}$ at $60^{\circ} \mathrm{S}$ making FRAM one of the highest resolution primitive equation models of the Southern Ocean run to date; Semtner and Chervin (1992) have run a $0.5^{\circ} \times 0.5^{\circ}$ global model and are currently 


\section{•}


working with even higher resolution models. The model can partially resolve the small-scale synoptic/mesoscale eddies found in the ocean. However, a cursory glance at the contours of Rossby radii in the South Atlantic produced by Houry et al. (1987) indicate that it will be many years before a fully eddy-resolving model will be possible.

The model was initialised as a cold $\left(-2^{\circ} \mathrm{C}\right)$, saline ( $36.69 \mathrm{ppt})$, motionless fluid and its temperature and salinity fields were relaxed toward the annual mean Levitus (1982) climatology for a 6-year period. The annual mean winds (Hellerman and Rosenstein, 1983) were increased linearly from zero to their steady value during the third year of integration. During this spin-up period the model produced a dynamically consistent set of fields (namely temperature, salinity and velocity) from the smooth climatology. Results from the end of this period are presented in the FRAM atlas (Webb et al., 1991). The integration was continued for a further 10 years. During this time, the seasonal climatological winds of Hellerman and Rosenstein (1983) were used to drive the ocean at the surface and the relaxation to the Levitus (1982) climatology was switched off except in the surface level. For the first 9 years of integration the model had harmonic lateral friction and linear bottom friction. For the final 7 years a mixture of harmonic and biharmonic lateral friction and quadratic bottom friction was used allowing the eddy field to develop more fully.

It is the purpose of this paper to examine the behaviour of FRAM within the South Atlantic Ocean. We will compare the model with observations where these are avail- able and go on to describe other features of interest. Most of the analysis which follows is of the last 6 years of the prognostic integration, where the model was allowed to develop without the restore-to-Levitus constraint. Thus, although the model remains far from a proper state of equilibrium with respect to its forcing, it still resembles the state of the ocean as described by the Levitus analysis fields.

\section{Hydrography and mean circulation}

The model hydrography is forced toward the highly smoothed Levitus (1982) climatology during the diagnostic phase and remains close to this throughout the (albeit short) integration. However, during the assimilation process a wealth of detail and small scale structure evolves. A number of fronts are formed in their observed positions. Eddies are spontaneously generated in western boundary currents and along the path of the ACC. Figure 1 shows the model surface temperature at the end of the diagnostic phase. Further sections can be found in the FRAM atlas (Webb et al., 1991).

The model appears to reproduce the circulation of the South Atlantic extremely well. Figure 2 illustrates contours of the mean volume transport stream function during the final 6 years of the integration. A coarse representation of the topography is also included in the figure to illustrate its effect on the circulation. To the north of the region is the sub-tropical gyre. The dynamics within this

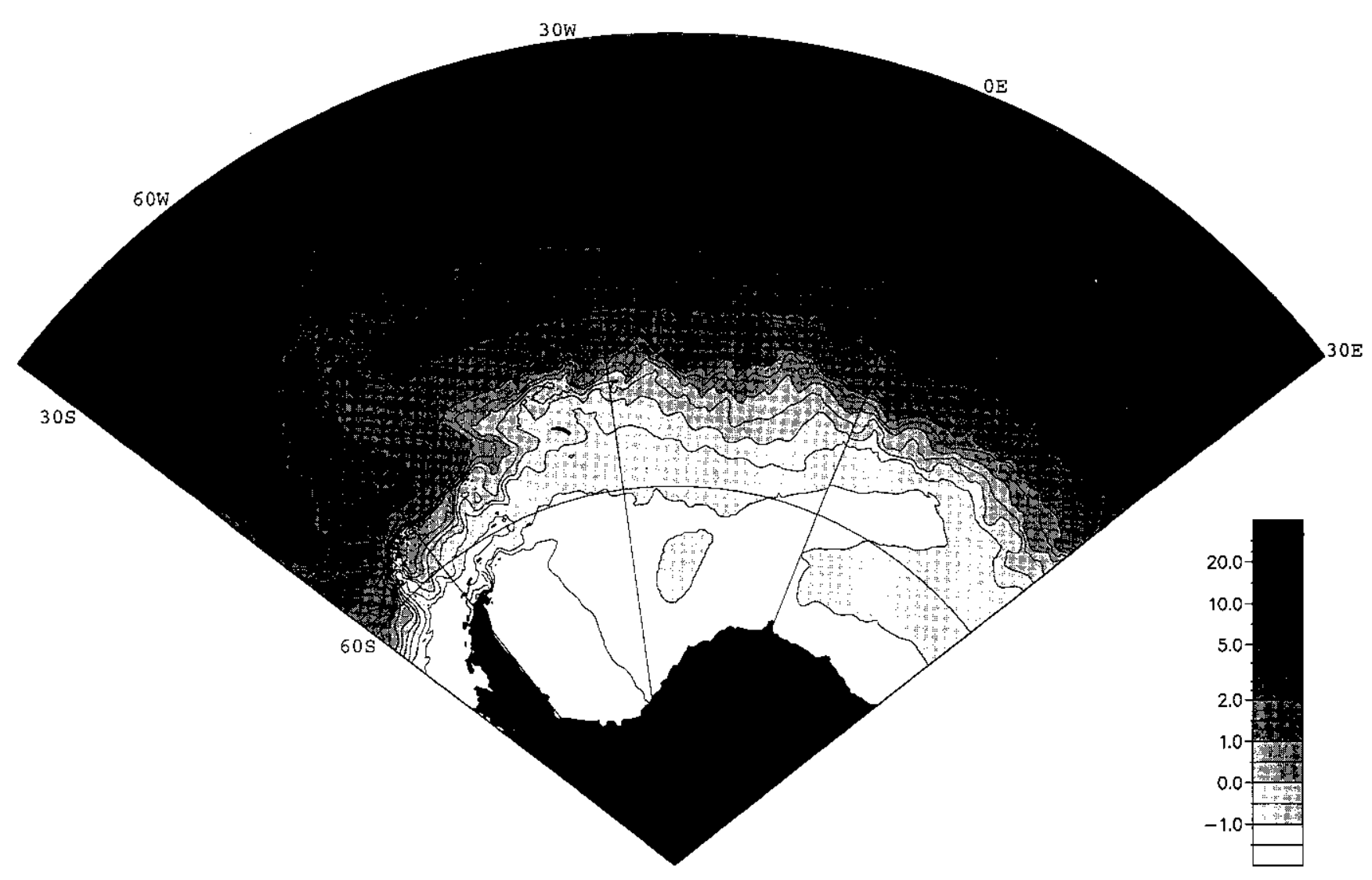

Fig. 1. The model surface temperature $\left(\right.$ in ${ }^{\circ} \mathrm{C}$ ) at the end of 6-year diagnostic phase 


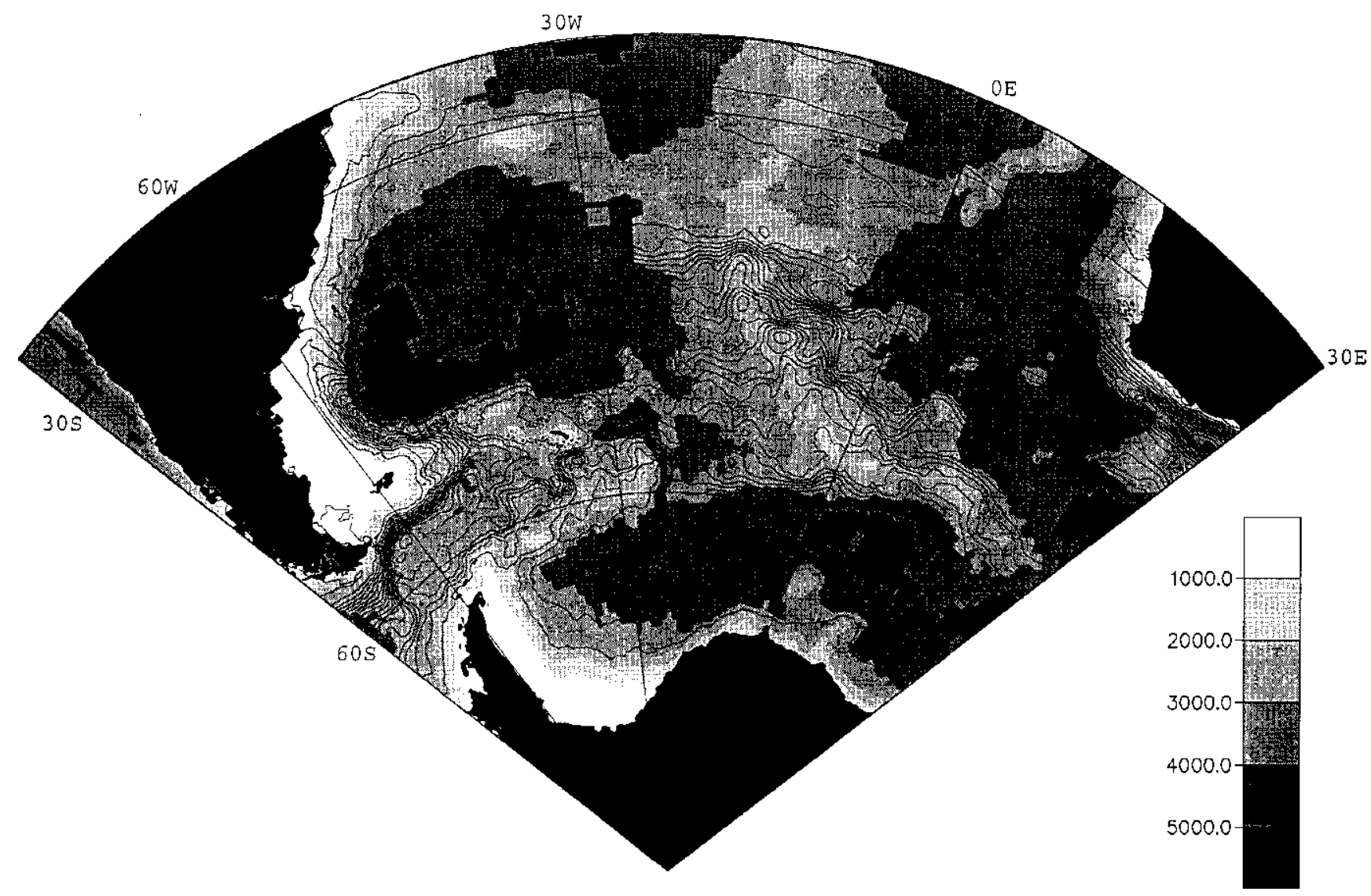

Fig. 2. The time mean volume transport stream function. The contour interval is $10 \mathrm{~Sv}$. Major topographic features (with a depth of less than $3000 \mathrm{~m}$ ) are represented by shading

region are largely Sverdrup and even major topographic features have little effect on the flow. The western boundary current (the surface Brazil Current and the southward-flowing NADW) of the gyre has a mean volume transport of $51 \mathrm{~Sv}\left(\mathrm{~Sv} \equiv 10^{6} \mathrm{~m}^{3} \mathrm{~s}^{-1}\right)$ at $37^{\circ} \mathrm{S}$. This value is much higher than the transports of 19-22 Sv estimated using a shallow reference level of $1400-1500 \mathrm{~m}$ (Gordon and Greengrove, 1986), and seems to support estimates of $70 \mathrm{~Sv}$ or more (Zemba and McCartney, 1988; Peterson, 1990) made using deeper reference levels. The maximum southward transport of the Brazil Current in FRAM has a mean of $82 \mathrm{~Sv}$. However, this includes a number of extreme events due to eddies in the confluence with the Falkland Current.

The Agulhas Current (the western boundary current of the wind driven sub-tropical gyre in the Indian Ocean) has a mean transport of $87 \mathrm{~Sv}$ at $32^{\circ} \mathrm{S}$; this can be compared with a mean Sverdrup transport of $47 \mathrm{~Sv}$. Gordon et al. (1987) estimated a transport of $95 \mathrm{~Sv}$. They also noted the large discrepancy with the Sverdrup transport and attributed the enhancement to a recirculation cell. This argument is also supported by FRAM which includes such a recirculation cell.

The ACC enters the South Atlantic through the Drake Passage as two jets. The northern jet is the strongest with a transport of about $130 \mathrm{~Sv}$, whilst the southern jet has a transport of $50 \mathrm{~Sv}$. In reality, three jets have been ob- served at Drake Passage (Nowlin and Clifford, 1982). In FRAM, the jet that occupies the middle of the passage merges with the northern jet. Many of the small narrow jets associated with the ACC can be seen. Toward the south of the region topographic effects are dominant and in general the flow follows contours of $f / H$ (see Fig. 2).

One point of note is the transport through Drake Passage, which at $180 \mathrm{~Sv}$ is higher than the generally recognised $130 \mathrm{~Sv}$ (Nowlin and Klinck, 1986). This overestimation of the transport in the ACC is endemic in primitive equation models. For instance, the global eddyresolving model of Semtner and Chervin (1992) has a transport of $200 \mathrm{~Sv}$ through Drake Passage. The additional transport in FRAM is mostly due to a stronger barotropic component of the flow than that observed in nature (Grose, 1992), Interestingly Matano (1993) has found that the Brazil Current (in his model) would only separate from the coast at its correct position if the ACC had a strength of $180 \mathrm{~Sv}$.

The volume transport of the Falkland Current in FRAM has a magnitude of $138 \mathrm{~Sv}$ at $52^{\circ} \mathrm{S}$ and $93 \mathrm{~Sv}$ at $45^{\circ} \mathrm{S}$. As with the transport through the Drake Passage, this is larger than observations suggest. Gordon and Greengrove (1986) and Piola and Bianchi (1990) both estimate approximately $10 \mathrm{~Sv}$ in the region $42-46^{\circ} \mathrm{S}$. These estimates are based on rather shallow reference levels and are suggested as lower limits. Using a full depth 


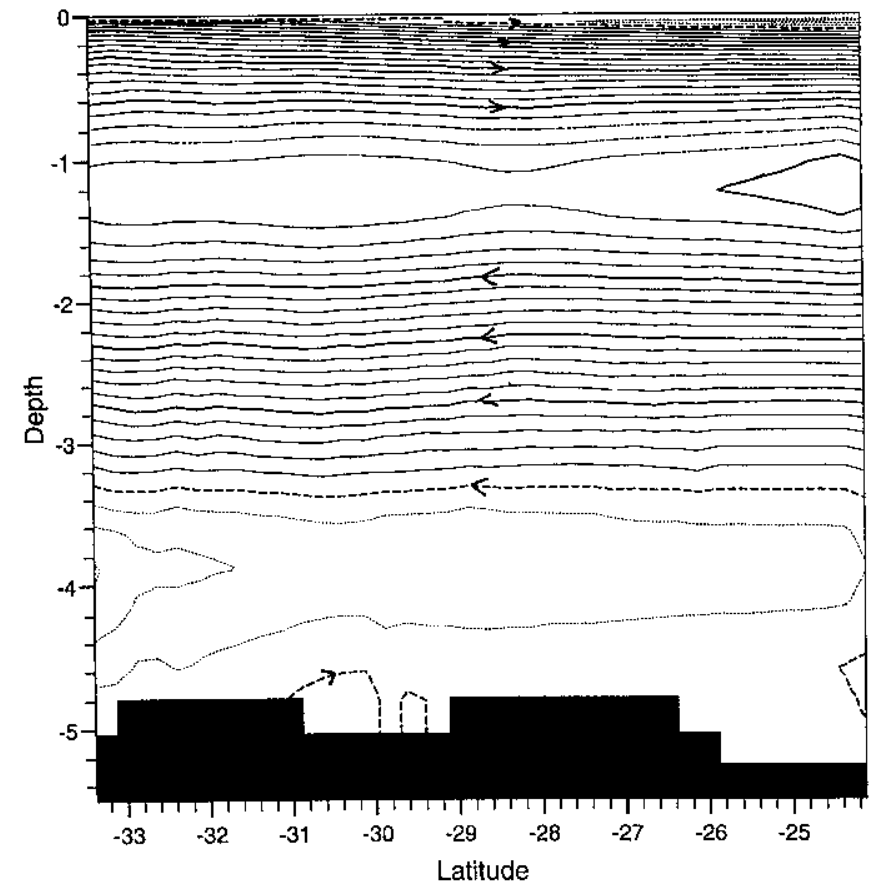

Fig. 3. The meridional overturning in FRAM. The contour is 1 Sverdrup. Every fifth contour is bold. The zero and negative contours are dashed

survey, Peterson (1990) suggests a transport of approximately $70 \mathrm{~Sv}$ at $42^{\circ} \mathrm{S}$, which is much closer to the FRAM prediction.

The main features of the volume transport across a transatlantic section at $32.5^{\circ} \mathrm{S}$ at the end of the diagnostic integration are described in Saunders and Thompson (1993). As might be expected, the mean volume transport for the prognostic phase, a few model years later, is similar. Figure 3 shows the vertically integrated meridional overturning stream function for latitudes north of the southern tip of Africa. The main features are an upper layer which includes warm surface waters and Antarctic intermediate waters moving equatorward, with a return flow of NADW. There is small equatorward transport of abyssal water. The overturning circulation of around $20 \mathrm{~Sv}$ is in broad agreement with preliminary estimates from WOCE cruise A11 (Saunders, 1993) and somewhat larger than the $15 \mathrm{~Sv}$ estimated by Rintoul (1991), although the northward transport of abyssal water in FRAM appears to be too small. A striking feature of Fig. 3 is its uniformity with changing latitude, implying a lack of vertical motion (in the zonal average). This is in contrast to the mean circulation in the other two basins, as described by Döös (1994), in which the streamlines show variations in depth with changing latitude.

The lack of bottom water in the diagnostic phase of the FRAM integration has been described by Saunders and Thompson (1993) and was ascribed to a lack of baroclinic structure in the Levitus data at depth. However, after running a limited area model with different representations of the Vema channel, Wadley and Bigg (1994) have suggested that the main cause is the removal (by smooth- ing the topography) of narrow deep channels. During the prognostic phase of the integration the situation was not improved. Furthermore, the relaxation of the surface-level temperature and salinity fields towards the annual mean Levitus values means that the very cold winter surface conditions necessary for bottom water formation are not found in the model.

Figure 4 illustrates the path of simulated drifters at the surface, 32.5, 1087.5, 1945.5 and $3071 \mathrm{~m}$ in the mean current. Comparing the illustrations, it can be seen that the ACC is predominantly barotropic whilst the waters north of $40^{\circ} \mathrm{S}$ have much more vertical structure. The illustrations of the upper $1000 \mathrm{~m}$ exhibit a large-scale structure similar to the schematic of Peterson and Stramma (1991, Fig. 2). Comparing the surface and 32.5-m tracks shows the deflection of the current by Ekman drift. Between $30^{\circ} \mathrm{S}$ and $60^{\circ} \mathrm{S}$, the surface layers are pushed northward. The strong offshore drift from Africa that causes upwelling is apparent. The Benguela Current is clearly seen, in the $32.5-\mathrm{m}$ plot, as a near-surface current. The Brazil Current is fed from the north at the surface and between 2000 and $3000 \mathrm{~m}$, whereas at intermediate depths $(1000 \mathrm{~m})$ it is fed by the sub-tropical gyre.

The meridional stream function (Fig. 3) gives no indication as to the location of the southward flowing NADW. It is clear from drifter tracks at 1945.5 and $3071 \mathrm{~m}$ that most of this water moves south as a deep western boundary current beside South America. The 3071-m plot also indicates a much weaker western boundary current following the mid-Atlantic ridge. Between $40^{\circ} \mathrm{S}$ and $50^{\circ} \mathrm{S}$ the NADW separates from South America and heads towards the east. Some of this water passes over the mid-Atlantic ridge, whilst the remainder flows around its southern end.

\section{Transient motion}

Drifter tracks at $32.5 \mathrm{~m}$, using instantaneous data from model day 4230, are shown in Fig. 5 for comparison with the mean fields presented above. The most striking feature of the figure is the Agulhas eddies moving westward into the South Atlantic. The fourth eddy from the east edge of the figure is just about to split into two, whilst the next two eddies to the west are the result of an earlier split. The other main region where eddies can be found is in the Brazil-Falkland Current confluence. Transient signals elsewhere are mainly due to meanders of currents rather than isolated eddies.

The eddy kinetic energy field at model level $2(32.5 \mathrm{~m})$ is illustrated in Fig. 6. Level 2 is chosen as it does not contain Ekman effects and is thus directly comparable with observations from satellite altimetry. Other model levels have a similar distribution of eddy energy due to the equivalent barotropic nature of FRAM (Killworth, 1992), although in general the magnitudes decay with depth. With reference to one of the altimeter-derived maps of eddy kinetic energy produced by Daniault and Ménard (1985) or Shum et al. (1990), it can be seen that FRAM has captured the distribution of eddy energy extremely well. Stevens and Killworth (1992) compared energy levels in FRAM with FGGE (First GARP Global Experiment) drifters and long-term current 

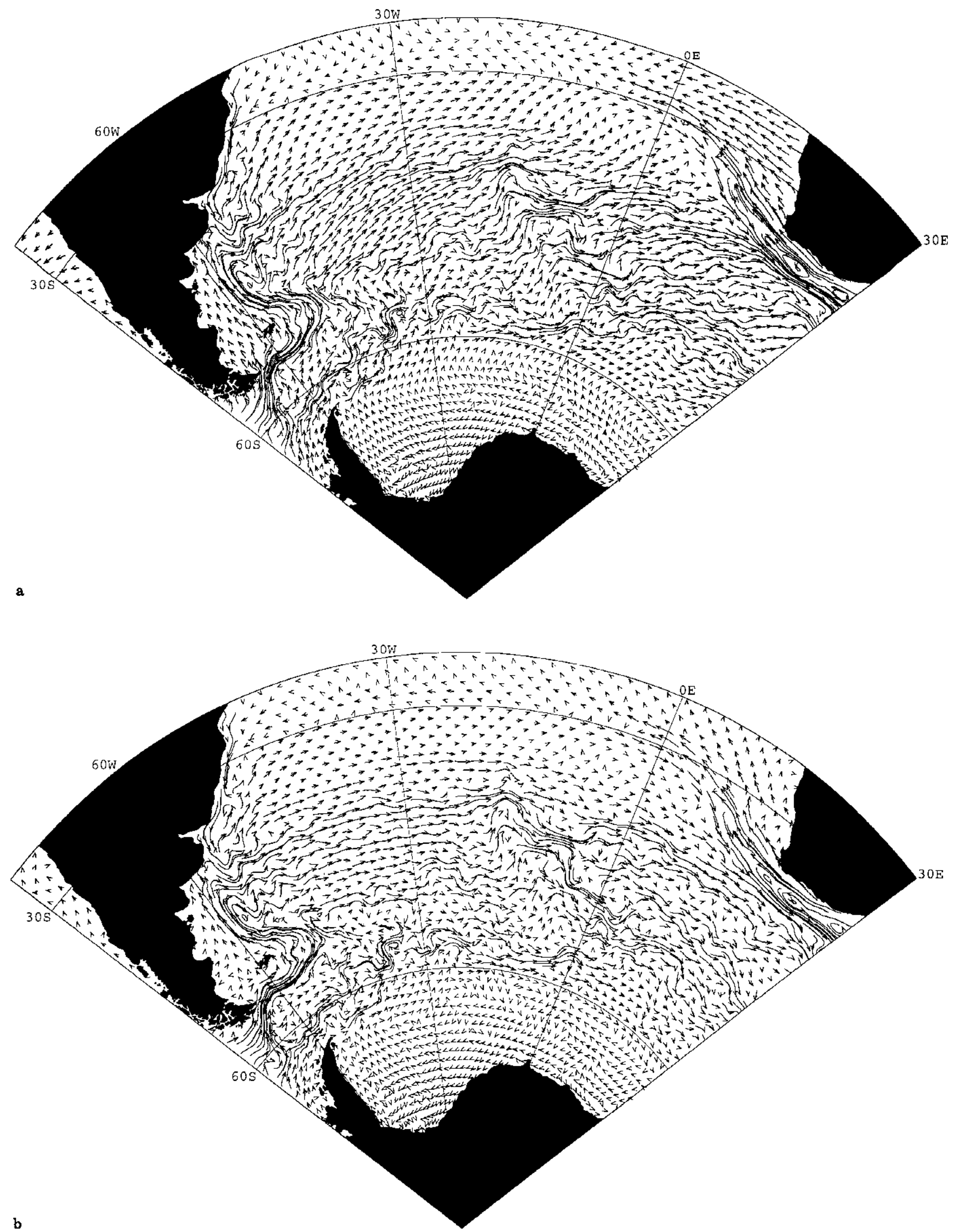

Fig. 4a-e. Simulated drifter tracks through the mean model current at a the surface with a 20 -day drift, b level $2(32.5 \mathrm{~m})$ with a 20 -day

drift, c level $13(1087.5 \mathrm{~m})$ with a 50-day drift, d level $17(1945.5 \mathrm{~m})$ with a 100 -day drift, e level $22(3071 \mathrm{~m})$ with a 200 -day drift 

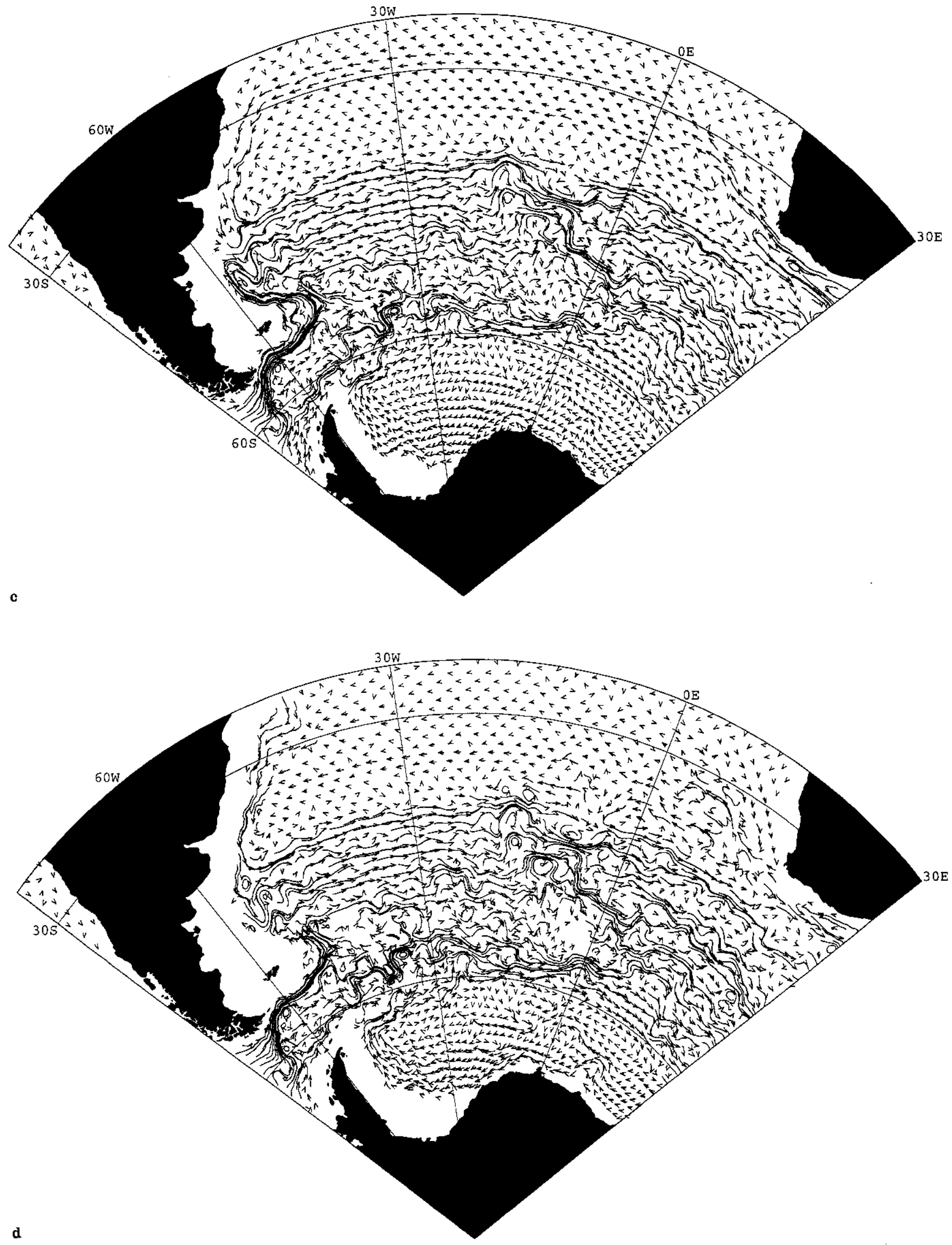

Fig, 4c-d. 


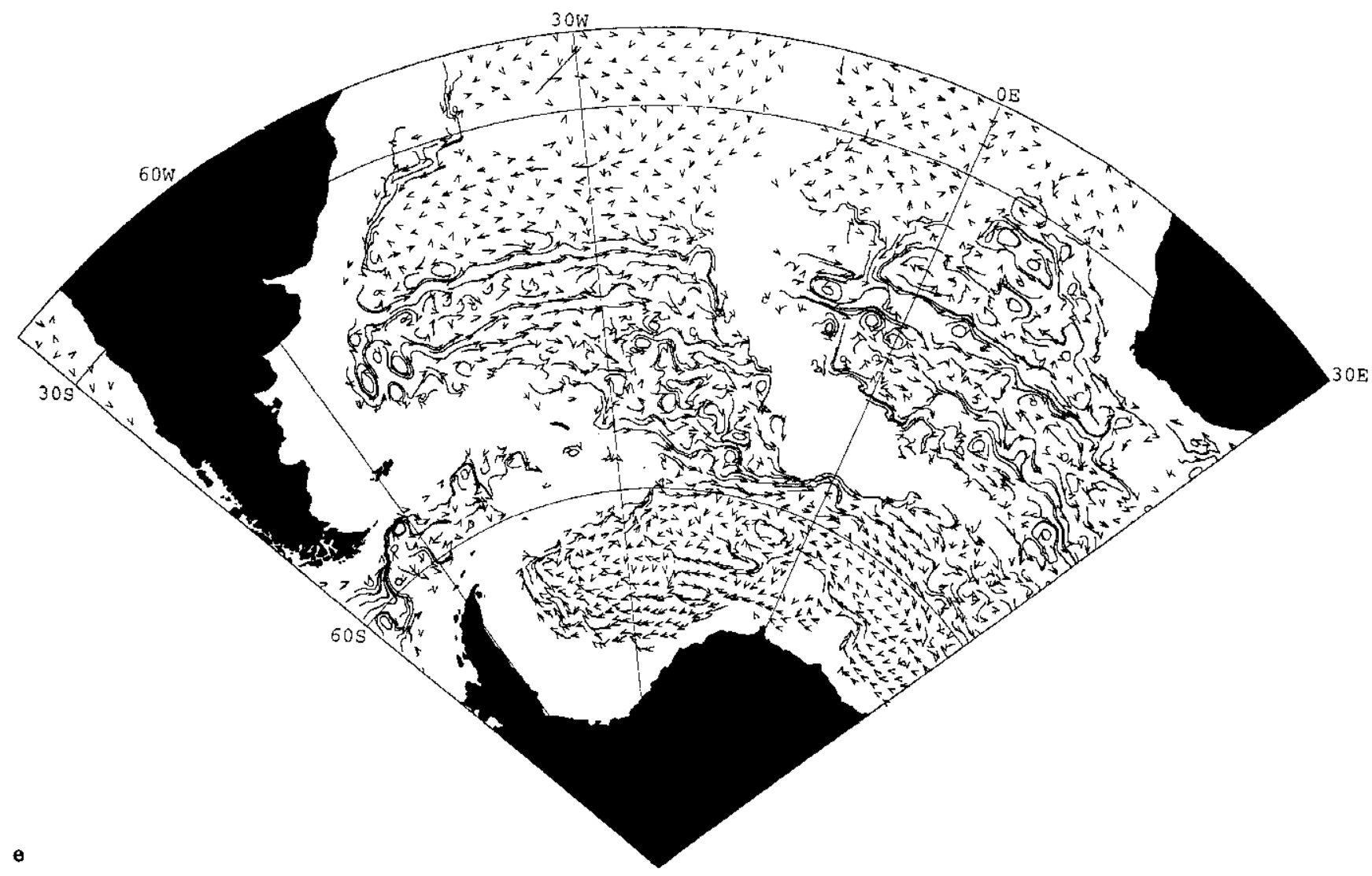

Fig. 4e.

meter moorings. They found reasonable agreement, although the magnitudes in FRAM were smaller, particularly in quiet regions. This is a common feature of general circulation models that only partially resolve eddies. For instance, Semtner and Chervin (1992) talk of 'eddy deserts'. The situation is improved with increased resolution (Boning and Budich, 1992). Areas of high eddy energy are found in western boundary currents, in the $\mathrm{ACC}$, and in the vicinity of major topographic features. One of the most eddy-active regions is the Agulhas Current retroflection zone. The path of Agulhas eddies is rather regular in FRAM, giving rise to a region of high eddy energy which can be tracked right across the Atlantic. In reality, the eddies follow more varied paths (Gordon and Haxby, 1990). The lack of variability in the paths in FRAM may be due to the smooth (spatially and temporally) wind forcing of the model. It is possible that daily winds (with interannual variability) from an atmospheric general circulation model would produce more varied tracks.

Figure 7 shows the eddy kinetic energy along a zonal section at $40^{\circ} \mathrm{S}$. To the west, the confluence of the Brazil and Falkland Currents produces an area of high eddy energy. The mid-Atlantic ridge is also an active region, with an indication of bottom trapping. There is also high energy in the region to the south of the Agulhas Current retroflection.

The sequence of stream-function 'snapshots' in Fig. 8 shows the formation and movement of Agulhas eddies. In FRAM, the eddies form further to the east than is ob- served (Lutjeharms and Van Ballegooyen, 1988). This is thought to be due to the smoothing (and shallowing) of a deep channel between the Agulhas Plateau and South Africa (Webb and Lutjeharms, personal communication). Approximately three Agulhas eddies are formed every year. This compares with the work of Gordon and Haxby (1990) who used a single year of GEOSAT data to estimate that five eddies are produced per year. It should also be noted that the FRAM eddies are larger in diameter at $440 \mathrm{~km}$ than the observed $290-350 \mathrm{~km}$.

Simple estimation of the volume of water contained in a typical Agulhas eddy, combined with estimates of typical translation speeds, or the number of eddies crossing into the South Atlantic per year, reveals that the eddies are responsible for a transport of approximately $30 \mathrm{~Sv}$ between the oceans. Using a method that calculates water mass exchanges from particle trajectories, Döös (personal communication) estimates that $23 \mathrm{~Sv}$ of Indian Ocean water leaves the model region through the open boundary in the South Atlantic. This indicates that, although some of the $30 \mathrm{~Sv}$ carried by the Agulhas eddies simply recirculates in the South Atlantic sub-tropical gyre, a significant amount goes into the North Atlantic conveyor belt.

Once the Agulhas eddies have been shed from the Agulhas Current retroflection, their behaviour is similar to that noted by Gordon and Haxby (1990). The eddies drift northwest until they meet the Walvis ridge (which runs from $6^{\circ} \mathrm{E} 25^{\circ} \mathrm{S}$ to $2^{\circ} \mathrm{E} 33^{\circ} \mathrm{S}$ ), where they lose much of the northward component of the drift. The eddies in 


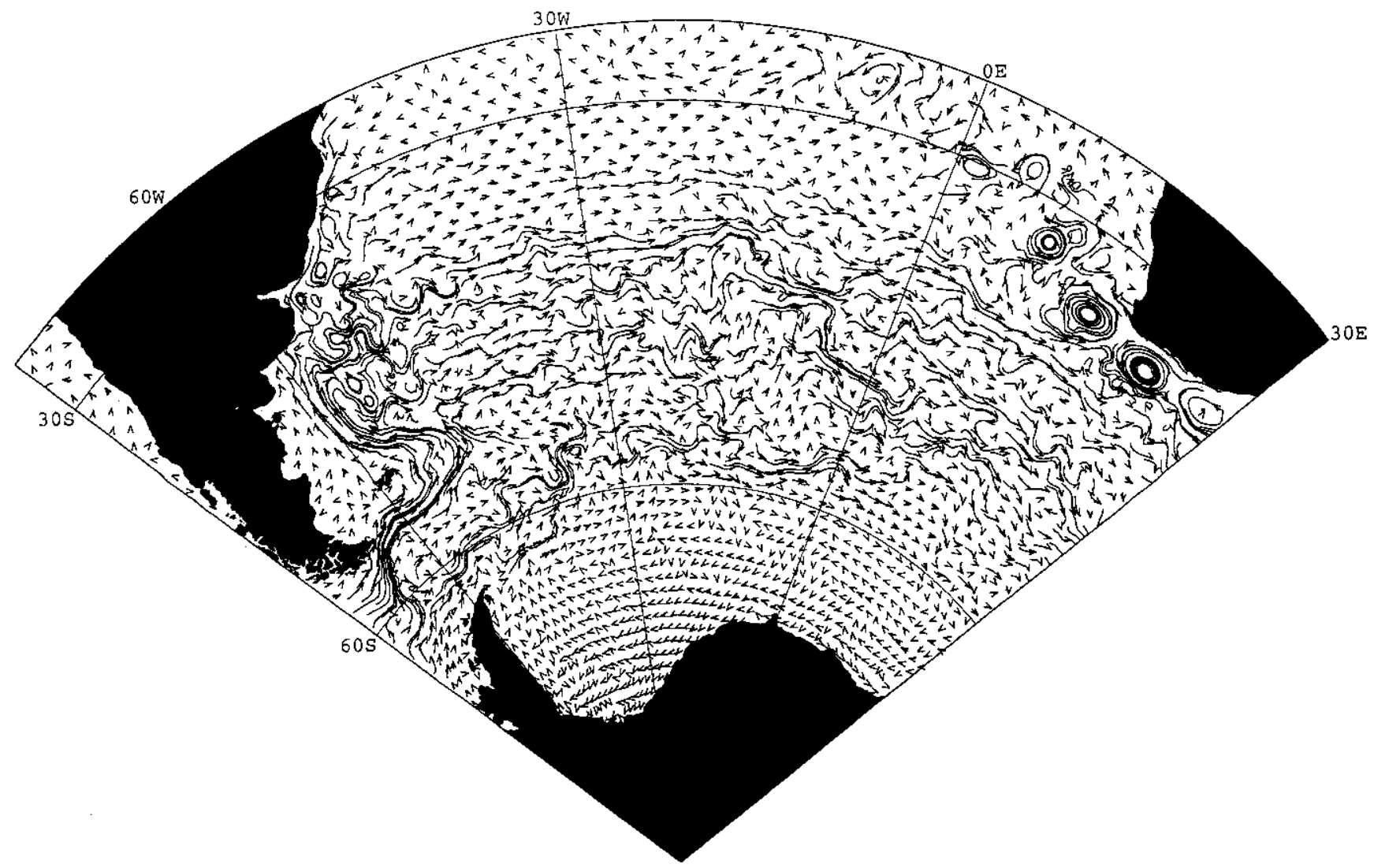

Fig. 5. Simulated drifter tracks through the day 4230 model current at level $2(32.5 \mathrm{~m})$ after a 20 -day drift

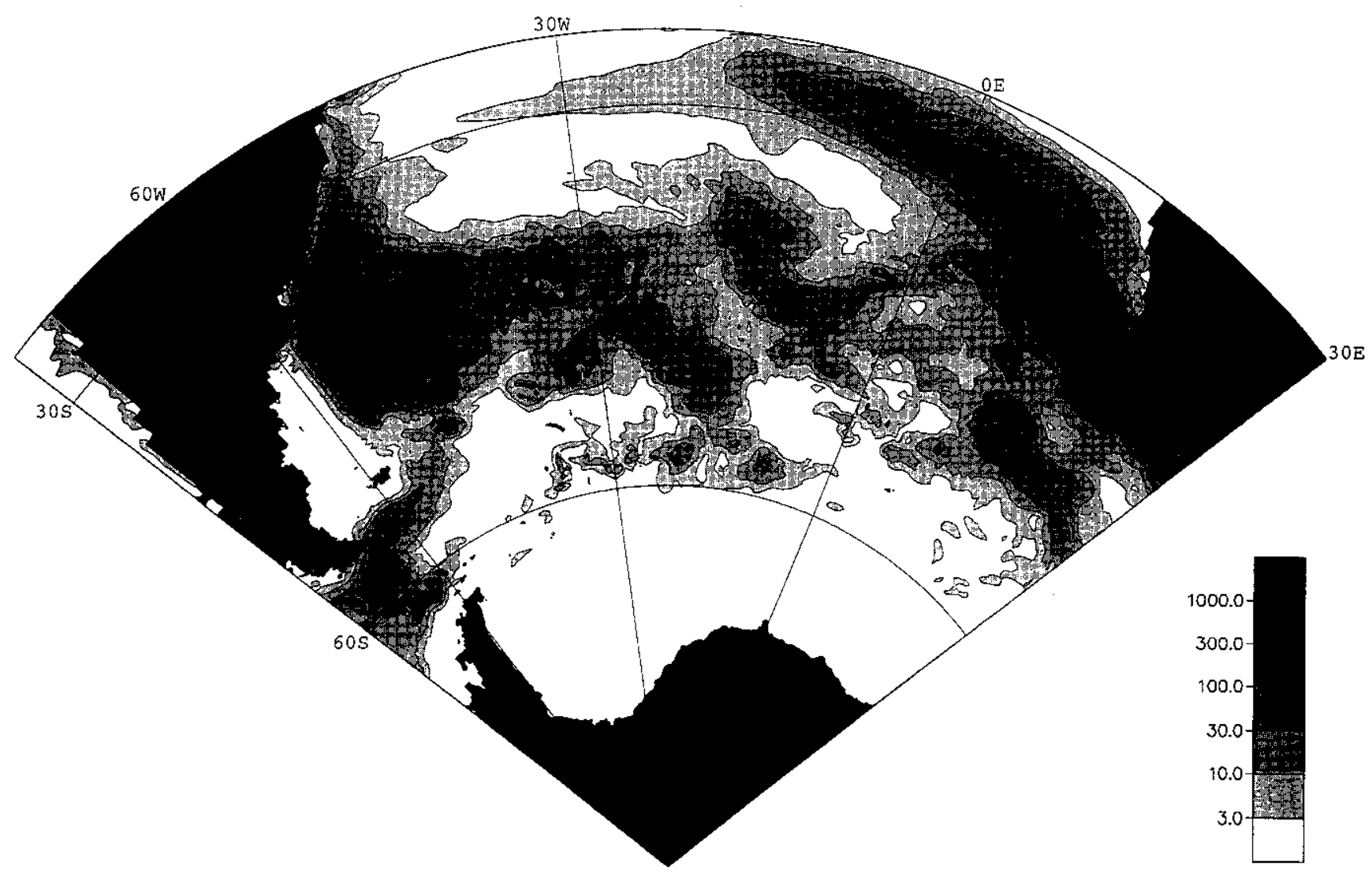

Fig. 6. The eddy kinetic energy $\left(\mathrm{cm}^{2} \mathrm{~s}^{-2}\right)$ at model level $2(32.5 \mathrm{~m})$ 


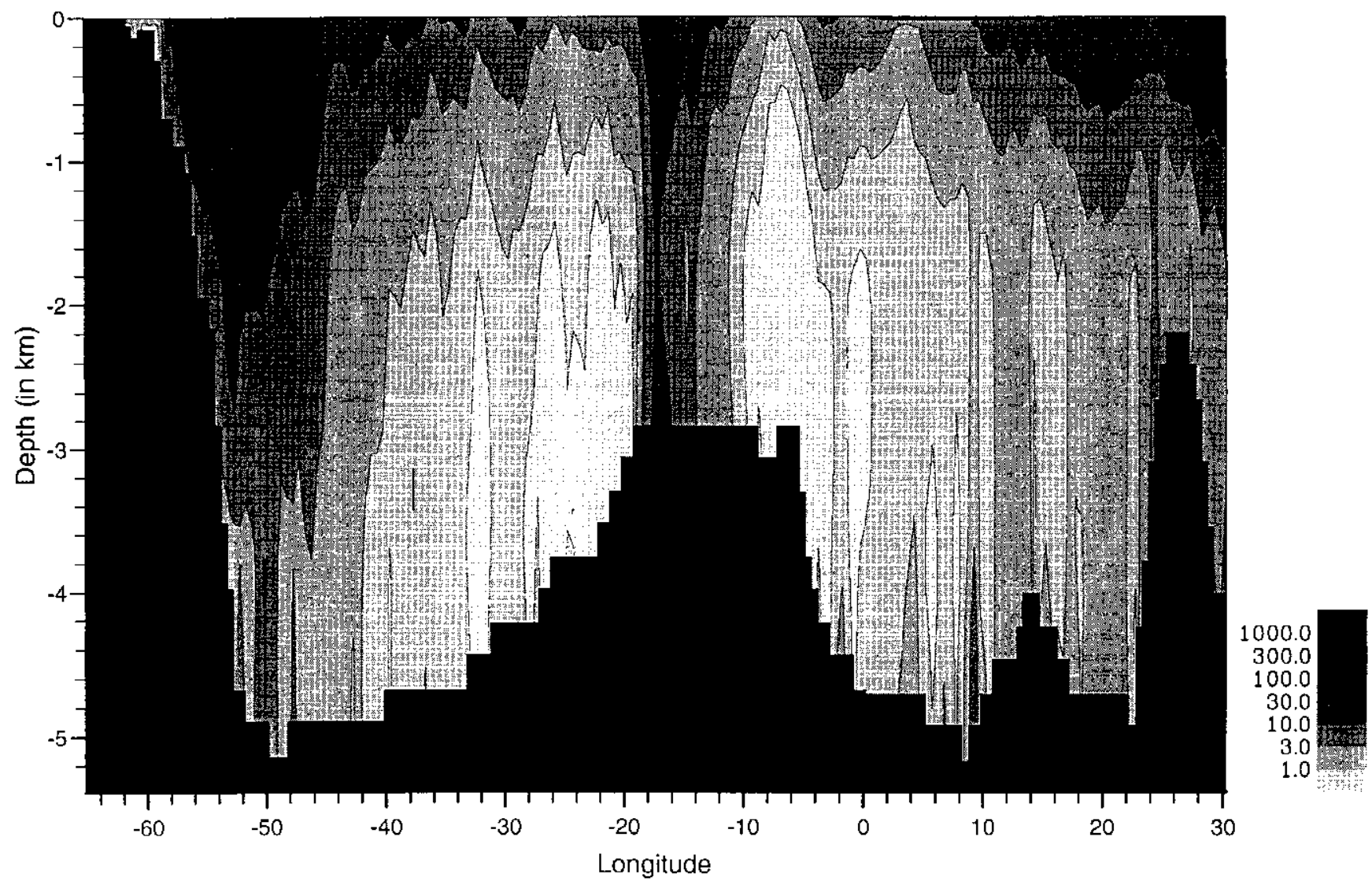

Fig. 7. The eddy kinetic energy $\left(\mathrm{cm}^{2} \mathrm{~s}^{-2}\right)$ along a zonal section at $40^{\circ} \mathrm{S}$

FRAM drift at a rate of about $6 \mathrm{~cm} \mathrm{~s}^{-1}$ compared to an observed speed of $5-8 \mathrm{~cm} \mathrm{~s}^{-1}$.

Olson et al. (1988) have made observations of the separation from the coast of the Brazil and Falkland Currents using 5.5 years of satellite data and drifters. They found that the mean latitudes of separation were $35.8 \pm 1.1^{\circ} \mathrm{S}$ for the Brazil Current and $38.6 \pm 0.9^{\circ} \mathrm{S}$ for the Falkland Current and that the distance between the separations varies by several degrees. In the model, however, the two currents appear to separate at the same point, with no clear evidence of two separate fronts and very little variation in latitude of this point.

Figure 9 shows the separation point and the position of the confluence front (as defined by the 0-Sv contour) for 72 monthly model realisations. The mean position is also shown. The figure suggests that the coarse representation of the coastline in the model exerts too strong an influence on the latitude of separation. The figure also shows how, after separation, the current extends to the south and then begins a series of meanders as it enters the South Atlantic interior. The variation in the southern limit of the Brazil Current excursions between 39 and $44^{\circ} \mathrm{S}$ agrees with the observations of Legeckis and Gordon (1982) of $38-46^{\circ} \mathrm{S}$, with the slightly lower range of values in the model probably due to the lack of variation in separation latitude.

Figure 10 shows a 6-year time series of the vertically integrated transport in the Brazil Current at $37^{\circ} \mathrm{S}$. The transport time series varies between 38 and $70 \mathrm{~Sv}$. The upper limit corresponds to the observed values discussed in Sect. 3. There is some indication of an annual signal. Comparisons with the Sverdrup transport at this latitude have shown that the wind forcing accounts for $43 \%$ of the variability. There is also variability in the model with a period of about 30 days.

Other time series from the model have been analysed and the results can be summarised as follows. There is little correlation between the strength of the Brazil and Falkland Currents. There is a correlation of 0.78 between the transport through the Drake Passage and the transport in the Falkland Current at $52^{\circ} \mathrm{S}$. The Falkland Current remains at $75 \%$ of the strength of the $\mathrm{ACC}$ to within a standard deviation of $1.4 \%$. The Sverdrup transport at $52^{\circ} \mathrm{S}$ (with mean $110 \mathrm{~Sv}$ ) correlates well with the transport through Drake Passage (correlation 0.75, mean $185 \mathrm{~Sv}$ ) and transport in the Falkland Current (correlation 0.67, mean $138 \mathrm{~Sv}$ ).
Fig. 8. The volume transport stream function in the region of South Africa at model day a 4520 , b 4540 , c 4560 , d 4580 , e 4600 , f 4620 , g 4640, h 4660 . The contour interval is $10 \mathrm{~Sv}$. Major topographic features (with a depth of less than $3500 \mathrm{~m}$ ) are represented by shading 

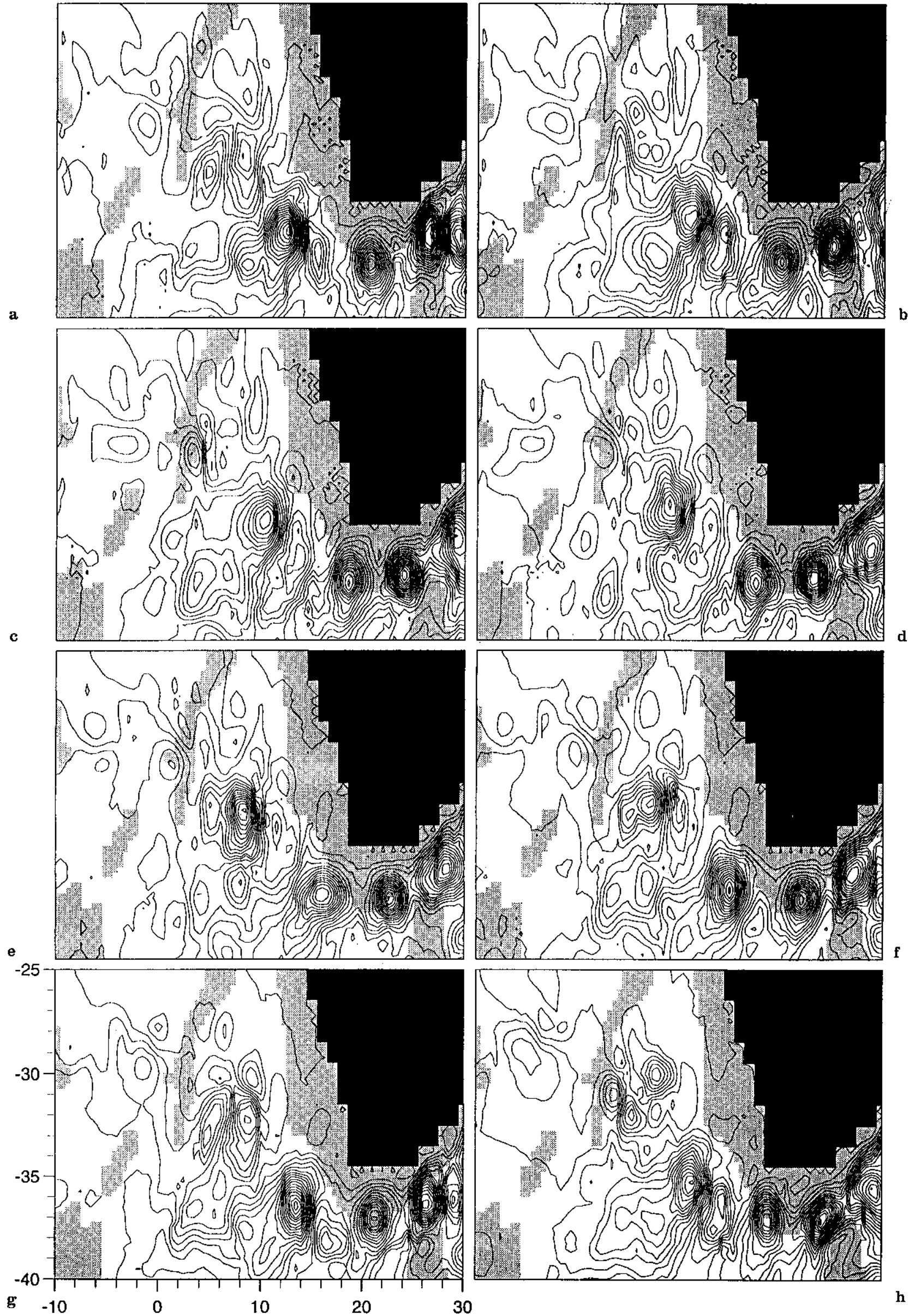


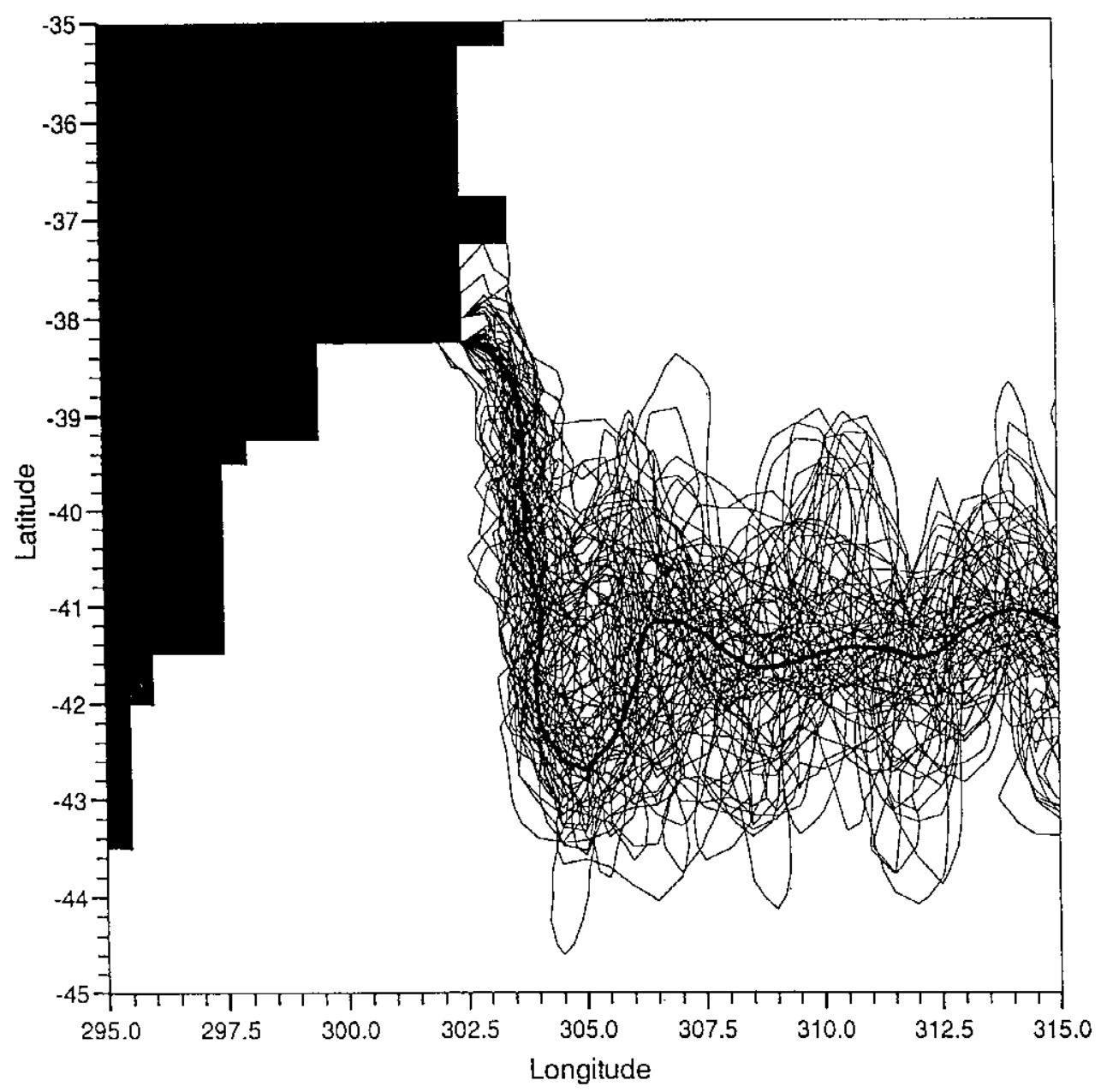

Fig. 9. Seventy-two monthly model visualisations of the Brazil-

Falkland Current confluence front (as defined by the $0 \mathrm{~Sv}$ contour). The mean position is also shown (heavy line)

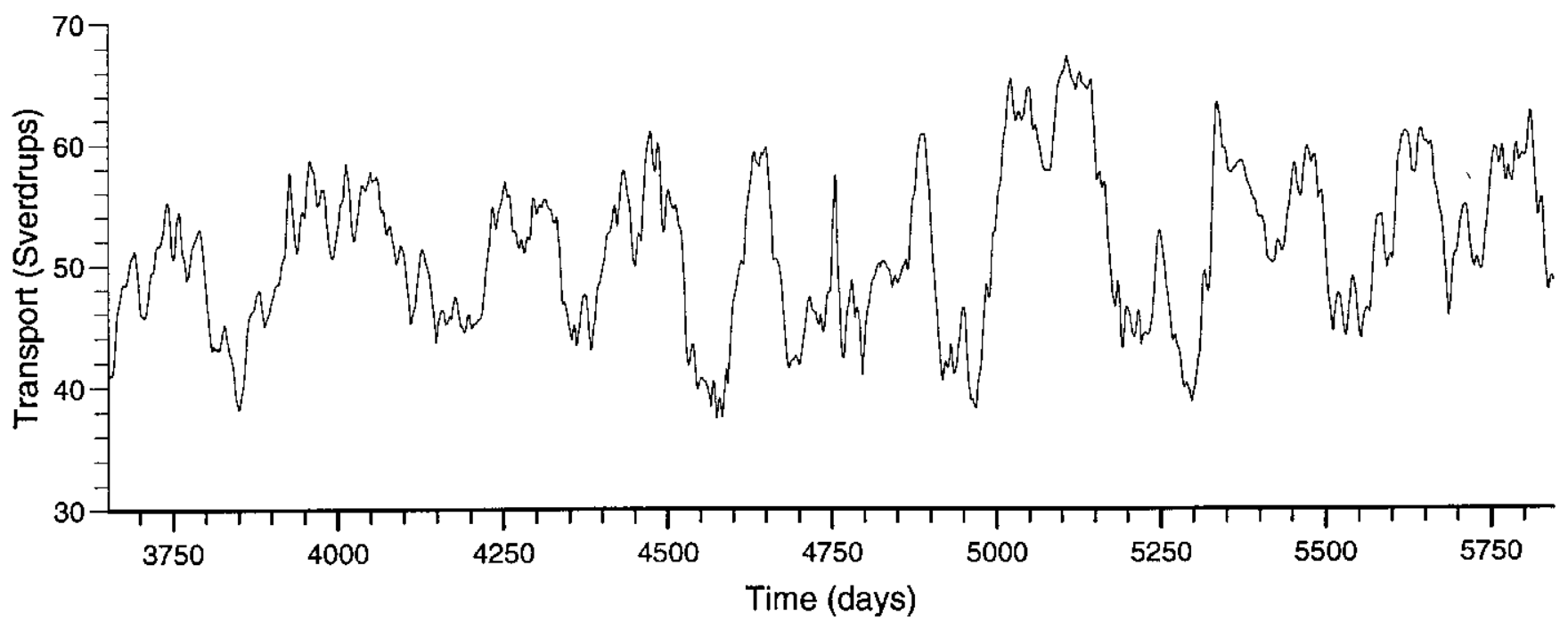

Fig. 10. A 6-year time series of volume transport (Sv) in the Brazil Current at $37^{\circ} \mathrm{S}$

\section{Heat transport}

A description of the modelled heat transport in the South Atlantic is given for completeness, although it should be noted that a fuller treatment of this topic, along with discussion of the transports in the rest of the FRAM region is in preparation.

The total equatorward transport of heat in the South Atlantic in the prognostic phase of FRAM is around $0.6 \mathrm{PW}$ for latitudes north of $34^{\circ} \mathrm{S}$ (the southern tip of 


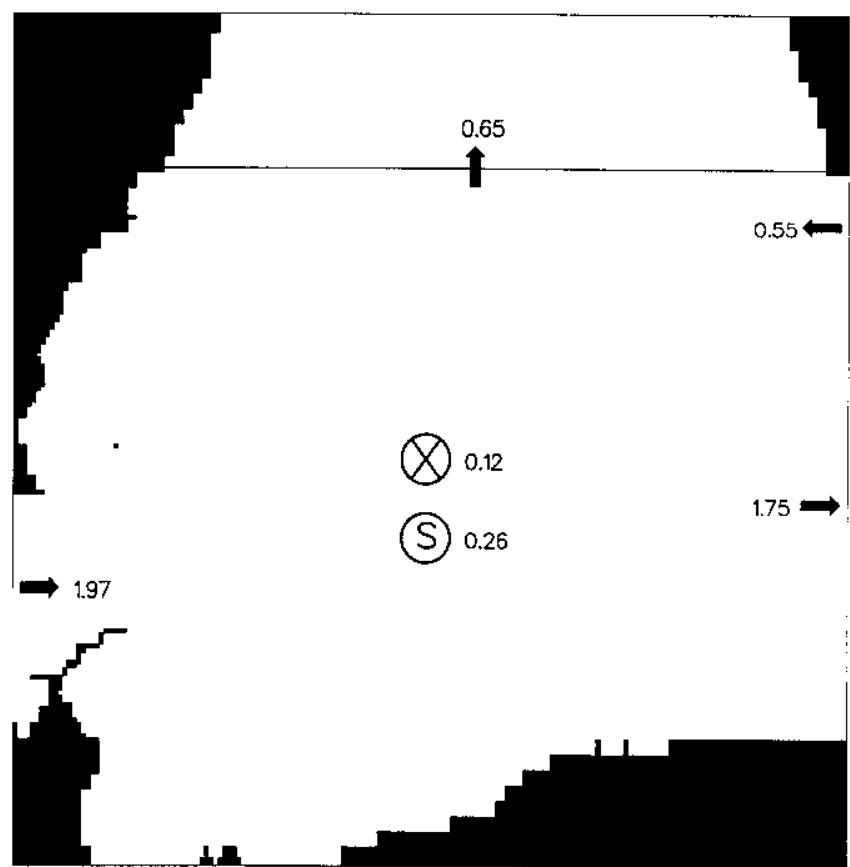

Fig. 11. The heat budget for the South Atlantic during the prognostic integration (units are $\mathrm{PW}$ ). The flux into the paper represents the effective surface flux south of $34^{\circ} \mathrm{S}$ due to the relaxation to the Levitus (1982) climatology, while the circled $S$ represents the heat storage for the same region

Africa). This transport is dominated by the overturning circulation described in Sect. 3; warm, shallow water moves northwards over a cold return flow of NADW, resulting in an equatorward overturning transport of around $0.8 \mathrm{PW}$. This is encountered by a small southward gyre heat transport of around $0.2 \mathrm{PW}$ due to water in the western boundary being warmer than the return flow in the gyre. The figure of $0.6 \mathrm{PW}$ lies well within the range of previous estimates given in Fig. 9 of Rintoul (1991), although it is likely that the underestimate of Antarctic bottom water transport described earlier will make this figure an overestimate.

There are two paths proposed in the literature by which water is exchanged between the ocean basins before being transported northwards in the Atlantic. In the 'warm water path' (Gordon, 1986), NADW leaving the Atlantic upwells in both the Pacific and Indian Oceans, whereupon it flows westward (with water from the Pacific entering the Indian Ocean through the Indonesian Passages) and completes its circuit by branching north in the Agulhas retroflection zone. The 'cold water path' described by Rintoul (1991) consists of the water in the Agulhas Current following the retroflection, entering the $\mathrm{ACC}$ and reentering the South Atlantic via the Drake Passage. In FRAM, the Indian Ocean supplies about $0.5 \mathrm{PW}$ to the South Atlantic in the Agulhas retroflection zone compared with Gordon's (1985) estimate of 0.023-0.47 PW, with a much smaller contribution to the northward heat flux in the Atlantic coming from the south.

Figure 11 shows the heat budget for the South Atlantic. The figures of $1.97 \mathrm{PW}$ through Drake Passage and
1.75 PW eastward south of South Africa are only meaningful if considered together (because of the non-zero but equal volume transport across both sections). The difference between these two heat transports $(0.22 \mathrm{PW})$ indicates the amount of heat lost by the ACC as it travels through the South Atlantic. Simulated surface fluxes (arising from the surface-level relaxation to the Levitus temperature field) supply a further $0.12 \mathrm{PW}$. However, not all of this heat is used to supply the northward transport in the Atlantic; some is used to heat up the Southern Ocean as the model has not completely reached thermodynamical equilibrium. This was unavoidable due to the computational expense of the integration.

The transient meridional heat transport in the region north of the tip of South Africa is small but interesting in that the flow is to the north (that is counter-gradient), reflecting the effect of Agulhas eddies. It is possible to calculate the heat transport due to transient processes at any point unambiguously, as the net volume flux of these processes is zero. Figure 12 shows the depth-integrated eddy heat flux over the South Atlantic. As one would expect, areas of high eddy heat flux correspond to areas of large eddy energy. With a few exceptions (notably, the region where the Agulhas eddies are propagating into the South Atlantic), the eddy heat flux is poleward. The eddy heat transport in the Atlantic has been compared with that found in the rest of the model, revealing that the Agulhas retroflection and the Brazil-Falkland Current confluence regions account for almost all the eddy transport, of $0.3 \mathrm{PW}$, at these latitudes. It is clear from the figure that calculations of eddy heat flux made by taking spot measurements and extrapolating over large areas of ocean (Bryden, 1979) are likely to be highly inaccurate.

Poleward eddy heat transports in the ACC in FRAM have been compared with those inferred by De Szoeke and Levine (1981), who used a novel technique to estimate heat transport due to mean geostrophic motions from climatalogical hydrographic and wind stress data. Thompson (1993) found that the eddies in FRAM advect only $0.12 \mathrm{PW}$ poleward across the ACC, compared to the previous authors' estimate of $0.45 \pm 0.30 \mathrm{PW}$. However, sub-gridscale processes, parameterized using a horizontal diffusion coefficient of $10^{2} \mathrm{~m}^{2} \mathrm{~s}^{-1}$, contribute a further $0.1 \mathrm{PW}$, bringing the model results into closer agreement with the hydrography. The fact that FRAM still has insufficient resolution to represent eddies adequately was suggested as a reason for any underestimate of eddy heat fluxes by the model.

\section{Summary}

The South Atlantic as simulated by a fine-resolution numerical model (FRAM) has been described. It is found that the model faithfully represents the main features of the large-scale circulation and as such can be thought of as having added value to the Levitus (1982) analysis fields. That is, the model has taken the smooth fields and produced a detailed and dynamically consistent view of the circulation. Eddies are starting to be resolved. The distribution of eddy kinetic energy is good, although the 


\section{Eddy heat flux}

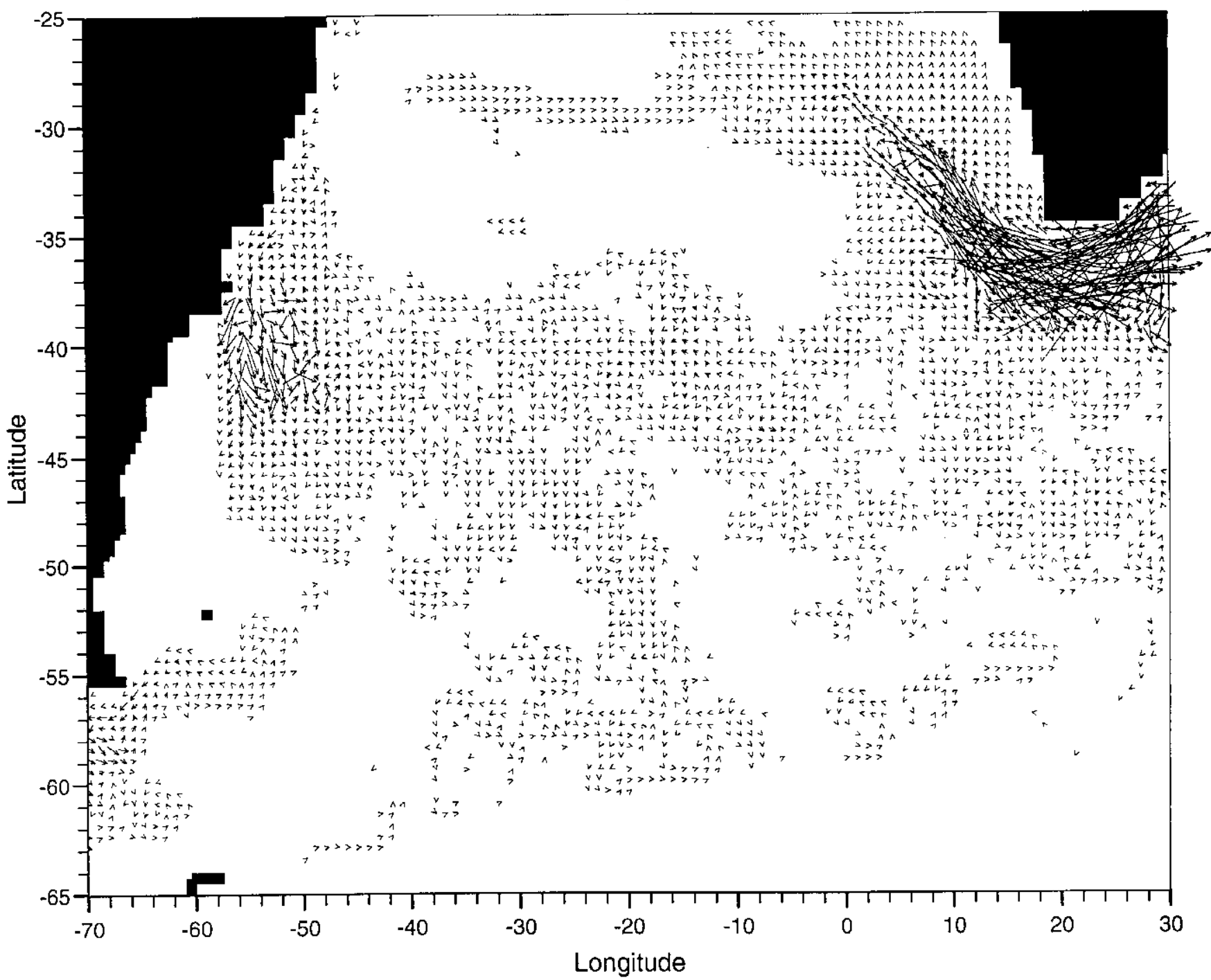

Fig. 12. Vectors of eddy heat flux. Only alternate vectors are plotted. The distance between grid points denotes a heat flux of $1 \mathrm{Sverdrup}{ }^{\circ} \mathrm{C}$

magnitude is underestimated. The meridional heat transport is equatorward and comparable to other estimates. The eddy heat transport is concentrated in a few small regions.

Acknowledgements. This work would not have been possible without the help of many other members of the FRAM group, in particular David Webb and Peter Killworth who provided useful comments on a draft of the manuscript. Andrew Coward, Matthew Beare and Jeff Blundell all contributed to the polar projection plotting programmes. Topical Editor, G. E. Weber thanks C. Provost and two other referees for their help in evaluating this paper.

\section{References}

Böning, C. W., and R. G. Budich, Eddy dynamics in a primitive equation model: Scnsitivity to horizontal resolution and friction, J. Phys. Oceanogr., 22, 361-381, 1992.

Broecker, W. S., The great ocean conveyor, Oceanography, 4, 79-89, 1991.
Bryden, H. L., Poleward heat flux and conversion of available potential energy in Drake Passage, Deep Sea Res., 37, 1-22, 1979

Cox, M. D., A Primitive Equation, 3-Dimensional Model of the Ocean, GFDL Occan Group Tech. Rep. No. 1, 1984.

De Szeoke, R. A., and M. D. Levine, The advective flux of heat by mean geostrophic motions in the Southern Ocean, Deep Sea Res., 28A, 1057-1085, 1981.

Döös, K., Semi-analytical simulation of the meridional cells in the Southern Ocean, J. Phys. Oceanogr., 24, 1281-1293, 1994.

Daniault, N., and Y. Ménard, Eddy kinetic energy distribution in the Southern Ocean, J. Geophys. Res., 90, 11877-11889, 1985.

FRAM group, Initial results from a finc-resolution model of the Southern Ocean, EOS, Trans. Am. Geophys. Union, 72, $169,174-175,1991$.

Gordon, A. L., Indian-Atlantic transfer of thermocline water at the Agulhas retroflection, Science, 227, 1030-1033, 1985.

Gordon, A. L, Interocean exchange of thermocline water, J. Geophys. Res., 91, 5037-5046, 1986.

Gordon, A. L., and C. L. Greengrove, Geostrophic circulation of the Brazil-Falkland confluence, Deep Sea Res., 33, 573-585, 1986. 
Gordon, A. L., J. R. E. Lutjeharms, and M. L. Gründlingh, Stratification and circulation at the Agulhas retroflection, Deep Sea Res., 34, 565-599, 1987.

Gordon, A. L., and W. F. Haxby, Agulhas eddies invade the South Atlantic: Evidence from GEOSAT altimeter and shipboard Conductivity-Temperature-Depth Survey, J. Geophys. Res., 95, 3117-3125, 1990.

Grose, T. J., Analysis of theoretical and observational techniques using the Fine-Resolution Antarctic Model, Ph.D. Thesis, University of East Anglia, Norwich, 1992.

Hellerman, S., and M. Rosenstein, Normal monthly wind stress over the World Ocean with error estimates, J. Phys. Oceanogr., 13, 1093-1104, 1983.

Houry, S., E. Dombrowsky, P. De Mey, and J.-F. Minster, BruntVäisälä Frequency and Rossby radii in the South Atlantic, J. Phys. Oceanogr., 17, 1619-1626, 1987.

Killworth, P. D., An equivalent-barotropic mode in the Fine-Resolution Antarctic Model, J. Phys. Oceanogr., 22, 1379-1387, 1992.

Legeckis, R., and A. L. Gordon, Satellite observations of the Brazil and Falkland Currents - 1975 to 1976 and 1978, Deep Sea Res., 29, 375-401, 1982.

Levitus, S., Climatological atlas of the world ocean. NOAA Prof. Pap., 13, U.S. Dept. of Commerce, 1982.

Lutjeharms, J. R. E., and R. C. van Ballegooyen, The retroflection of the Agulhas Current, J. Phys. Oceanogr., 18, 1570-1583, 1988.

Matano, R. P., On the separation of the Brazil Current from the coast, J. Phys. Oceanogr., 23, 79-90, 1993.

Nowlin, W. D., Jr, and J. M. Klinck, The physics of the Antarctic Circumpolar Current, Rev. Geophys., 24, 469-491, 1986.

Nowlin, W. D., and M. Clifford, The kinematic and thermohaline zonation of the Antarctic Circumpolar Current at Drake Passage, J. Mar. Res., 40, 481-507, 1982.

Olson, D. B., G. P. Podesta, R. H. Evans, and O. B. Brown, Temporal variations in the separation of Brazil and Malvinas Currents, Deep Sea Res., 35, 1971-1990, 1988.

Peterson, R. G., On the volume transport in the southwestern South Atlantic Ocean, Abstract, EOS, Trans. Am. Geophys. Union, 71, $542,1990$.
Peterson, R. G. and L. Stramma, Upper-level circulation in the South Atlantic Ocean, Prog. Oceanogr., 26, 1-73, 1991.

Piola, A. R., and A. A. Bianchi, Geostrophic mass transports at the Brazil/Malvinas Confluence, Abstract, EOS, Trans. Am. Geophys. Union, 71, 542, 1990

Rintoul, S. R., South Atlantic interbasin exchange, J. Geophys. Res. 96, 2675-2692, 1991.

Saunders, P. M., WOCE cruise A11 in the South Atlantic, Ann Geophysicae, 11 (Suppl. 2), Book of abstracts, EGS Gen. Ass., Wiesbaden, p. C166, 1993.

Saunders, P. M., and S. R. Thompson, Transport, heat and freshwater fluxes within a diagnostic numerical model (FRAM), J. Phys. Oceanogr., 23, 452-464, 1993.

Semtner, A. J., and R. M. Chervin, Ocean general circulation from a global eddy-resolving model, J. Geophys. Res., 97, 5493-5550, 1992

Shum, C. K., R. A. Werner, D. T. Sandwell, B. H. Zhang, R. S. Nerem, and B. D. Tapley, Variations of global mesoscale eddy energy observed from GEOSAT, J. Geophys. Res., 95, 17865-17876, 1990.

Stevens, D. P., The open boundary condition in the United Kingdom Fine-Resolution Antarctic Model, J. Phys. Oceanogr., 21, 1494-1499, 1991.

Stevens, D. P., and P. D. Killworth, The distribution of kinetic energy in the Southern Ocean: A comparison between observations and an eddy-resolving general circulation model, Phil. Trans. R. Soc London B, 338, 251-257, 1992.

Thompson, S. R., Estimation of the transport of heat in the Southern Ocean using a fine-resolution numerical model, $J$. Phys. Oceanogr., 23, 2493-2497, 1993.

Wadley, M. R., and G. R. Bigg, Interbasin exchange of bottom water in ocean general circulation models, J. Phys. Oceanogr., in press, 1994.

Webb, D. J., P. D. Killworth, A. C. Coward, and S. R. Thompson, The FRAM atlas of the Southern Ocean, Natural Environment Research Council, Swindon, U.K, 1991.

Zemba, J. C., and M. S. McCartney, Transport of the Brazil Current: It's bigger than we thought, EOS, Trans. Am. Geophys. Union, 69, $1237,1988$. 
